\title{
The Use of Transformative Learning Strategy in Teaching Writing Recount Text
}

\author{
Sri Dewi Yanti \\ Department of English Applied \\ Linguistics \\ Universitas Negeri Medan \\ Medan, Indonesia \\ Sridewiyanti12@yahoo.com
}

\author{
Anni Holila Pulungan \\ Department of English Applied \\ Linguistics \\ Universitas Negeri Medan \\ Medan, Indonesia
}

\author{
I Wy Dirgeyasa \\ Department of English Applied \\ Linguistics \\ Universitas Negeri Medan \\ Medan, Indonesia
}

\begin{abstract}
The objective of the research is to describe the process of teaching writing recount text by using Think-TalkWrite strategy and to find out the responses of students toward using Think-Talk-Write strategy. The research was a descriptive qualitative research. The subject of the research is Grade $X$ of Setia Budi Abadi Senior High School students in the 2017/2018 academic years. Random sampling is used in taking the sample. In the research, the writer recorded and interviewed the students directly toward Think-Talk-Write strategy. Findings show the use of Think-Talk-Write strategy can help students learning writing recount text and the students can learn more active in the classroom. The teacher explained and instructed in procedural teaching practice to Think-Talk-Write strategy usage. This strategy could make students feel relax and made them motivated in teaching learning process. Therefore, the students will not find the difficulty to generate and to organize their ideas in writing recount text.
\end{abstract}

Keywords - Teaching writing; Think-Talk-Write strategy; Writing; Recount text.

\section{INTRODUCTION}

Writing skill is one of the four language skills that should be developed in learning English at Senior High School. Among the four language skills, writing is viewed as a difficult skill by almost all students. They have to organize ideas, produce meaningful and structured sentences.

Li said that writing is widely acknowledged as an intricate and complex task as well as the most difficult of the language abilities to acquire. The work of writing is presented in the form of text types, usually known as genres, which are closely related to the purpose of each type. Writing recount is the text type that is taught at the tenth grade[7].

Hudgson (2000) said that "Recount text tells about something happened in the past." It can happen to the writer or someone else. The purpose of recount text is to retell an event or events. The writers or speakers are expected to express their ideas about the experience or last event focused to inform the readers. It means the writers or the speakers want the reader catch their ideas and feeling about the story in the text. So the reader can imagine the writer situation and condition related to the text that they have written.

The researcher has observed the students in SMA Setia Budi Abadi Perbaungan. The researcher found that the students faced some problems in writing recount text. The main problem is related to the ideas they will write in recount text. They found it difficult to generate and to organize their ideas. The researcher also found a gap between students ${ }^{\text {ec }}$ failure and curriculum expectations in writing achievement due to lack of basic knowledge of English, especially grammar and vocabulary of each student in grade ten.

Another problem may come from the strategy used by the teacher in teaching recount text. Some of teachers still did not model how to write a recount text in front of the students. Instead, they used the conventional strategy that is only by giving the example of recount and narrative texts that they have prepared at home. As a result, the students only learn from the example without witnessing the process of how recount text is written.

Based on the problems above, the researcher took Think Talk Write strategy as the way to teach writing skill to the students, especially in creating recount text. The researcher believes that through Think Talk Write strategy, the students can express their ideas to be better.

Think-Talk-Write (TTW) is a strategy that facilitating the exercise of language both oral and written fluently [5]. This strategy based on the interpretation that learning is a social action. Think-Talk-Write strategy encourages the students to think, talk, and write based on the particular topic. ThinkTalk-Write strategy is used to develop the writing fluently and exercise the language before write.

Related to the research that has been done by Suminar and Putri conducted research on the effectiveness of TTW (thinktalk-write) strategy in teaching writing descriptive text. She concluded that Think Talk Write strategy significantly 
affected the students ${ }^{\text {ee }}$ achievement in writing descriptive text, because this strategy is designed to let the students sharing their ideas to write in good text. So it is expected for the students to write a text especially descriptive well. It can stimulate students ${ }^{\text {se }}$ think their own idea and share to others. Therefore, the students will find by applying Think Talk Write strategy is easier to write down their idea into a good text[8].

Thus, this research aims to describe the process of teaching writing recount text by using Think-Talk-Write strategy and to find out the responses of students toward using Think-TalkWrite strategy. The researcher conducted this research at grade X of Setia Budi Abadi Senior High School students in the 2017/2018 academic years.

\section{LITERATURE REVIEW}

\section{A. Definition of Think Talk Write (TTW)}

According to Huinker and Laughlin in Zulkarnaini, "The Think-Talk-Write strategy builds in time for thought and reflection and for the organization of ideas and the testing of those ideas before students are expected to write." It means that this strategy basically built through thinking then talk by sharing ideas with their friends before writing. For more effective, firstly, students are divided into group consist of 4-6 students for each group[6].

This strategy can be facilities the students in writing because the students practice work together or cooperative learning. The student will be relax if they work together, the student can think what they know and they share with a group, finally they can write on paper after they discussion with their group.

\section{B. Steps of Think Talk Write (TTW)}

Based on Yamin and Ansari these are the steps of Think-

Talk- Write (TTW) are:

a. Students read a text and make notes about what they have read (Think), then discuss with their group.

b. The students do interaction and collaboration with their group to discuss the notes (Talk). In this activity, the students use their own words to explain ideas in their group.

c. The students express the result of discussion in form written text (Write). Writing can help the students realize one of learning purpose and measure students understanding the material have learned.

d. The last learning activity is make a reflection and conclusion about what they have learned. One of the students from each group presentation their answers, while other group give an idea[9].

\section{Strengths and Weaknesses of Think-Talk-Write (TTW)} Strategy

\section{Strengths of Think-Talk-Write (TTW)}

Think-Talk-Write (TTW) has some strength. First, helping students to understand the concepts by doing thinking, talking, and writing activities and use them in finishing the task. Second, comprehension is reinforced and enhance by adequate processing time [2]. Third, learning is enhanced when students read, listen, speak, and write. Forth, it encourages the students to develop their social interaction communicatively. Students can develop interpersonal and communication skills [6]. Fifth, after being able to share their problems with other people, the students will feel relax and they will be motivated to take parts in teaching-learning activity.

\section{Weaknesses of Think-Talk-Write (TTW)}

Even though the weakness of Think-Talk-Write, namely it is time consuming for its implementation, teacher will face difficulties in monitoring and controlling the collaborative groups in Talk session of TTW strategy, so roles and standards must be stressed from the beginning, Individual differences among students in a heterogeneous group will make the students who can't study collaboratively prefer to keep silent in Talk session, so the discussion in group cannot run smoothly and the teacher should be able to design the appropriate instrument for the students"e assessment.

Genre

The genre perspective covers two distinctive dimensions in teaching and learning writing. First, genre is a kind of text or writing work itself. It views that the language (writing form) must be related to social function. Social function of the text then implies a certain social environment and place where and when the text is used. Second, genre as a process or strategy of how the writing work is developed, taught, and learned. Genre as an approach, of course, provides some stages or steps to follow. These will guide the writer systematically in order to be able to produce the writing work itself.

Dirgeyasa states that there are fifteen types of the genre writing, they are; recount, news item, procedure, descriptive, narrative, report, analytical exposition, hortatory expotition, spoof, explanation, discussion, critical review, commentary, book review, and anecdote [1].

Recount text is one of the text genres that the students learn at grade ten. The text is written with the purpose to inform to the readers or people about something that happens in the past. It can be experiences and events. Coggan confirms recount text is written to retell with purpose of either informing or entertaining their audience or readers (or both). The writers or speakers are expected to express their ideas about the experience or last event focused to inform the readers.it means the writers or the speakers want the reader catch their ideas and feeling about the story in the text. So, the reader can imagine the writer situation and condition related to the text that they have written. 
According to Gerot and Wignell the generic structure of recount text usually consists of:

a) Orientation : in the orientation, the writer of recount text provides the setting or place where and when the story happens

b) Series of Events : in the event, the writer of recount text tells about what happened in sequencing

c) Re-orientation : it is a closing statement. Here, the writer of recount text may state a closing of the story. It can be expressing of heart feeling after doing the events in the story or it can be a conclusion of the story[4].

\section{METHOD OF THE RESEARCH}

In this research, the researcher used descriptive qualitative design. Freeman and Long that descriptive qualitative is the study which is designed to identify and describe the observed phenomena in the form of words rather than in number [3]. This study is designed to describe some activities at the classroom in teaching writing recount text by using Think Talk Write (TTW). The researcher used one class as the subject at grade X of Setia Budi Abadi Senior High School students in the 2017/2018 academic years.

To get the data from the observation, the researcher conducted the observation three times and each observation lasted $2 \times 45$ minutes or 90 minutes. The researcher only chose one class that consists of 32 students, 24 girls and 8 boys.

Techniques used in this research were a writing task and interview. The researcher asked the students to make recount text based on the topics given. Then, after giving writing task to the students, the researcher interviewed the students.

\section{FINDINGS AND DISCUSSION}

In the first observation, the researcher observed the teacher and the student's activities during teaching and learning process using TTW strategy. The topic discussion was about "My Idol". Firstly, teacher asked the students about their activities and materials at the previous meeting. Students told their activities and materials at the previous meeting. After that, teacher asked students experiences and events in the previous time and the students responded about their experience, then the teacher delivered the material to the students and informed the procedures of teaching that are going to do.

In this activity, teacher began delivering materials on recount text. After that, students analyze recount text and make some notes based on what they have read (Think), then discuss with their group. Then, students make interaction and collaboration with their friends in a group to discuss the notes they made in "talk" activity. In this activity, the students use their own words to explain ideas in their group. And the last, students construct their knowledge by themselves in creating recount text as the result of collaboration in "write" activity. The last learning activity is make a reflection and conclusion about what they have learned. One of the students from each group presentation their answers, while other group give an idea. The best work of the group was read in front of the class and the best result one of the groups would get reward from the teacher. It motivated the students to produce the best writing in recount text.

But before doing discussion, the teacher asked students to make a group in the classroom. Each group consisted 4-6 students, each group complete the worksheet that provided by the teacher.

Thus, the researcher observed the teacher whether she did each steps of Lesson Plan or not using observation checklist for Lesson Plan application and also observed the students ${ }^{\text {ec }}$ activities using interview to get the students" response.

The second observation was the same as the first observation, the researcher observed the application of TTW strategy in teaching and learning process, but used different topic. The topic discussion was about "B.J Habibie". In the third observation, the researcher collected the data about the students" recount text and students" response to the TTW strategy which was they passed in two meetings before. The teacher distributed a paper test for each student; the students did their writing by themselves without discussion with their friends as in the previous meeting.

After all of the students gathered their paper test, the teacher then distributed the studentse opinion sheet that was consisting of several questions about students opinion during teaching and learning process using TTW strategy in the two last meeting before.

The result of studentse activities during teaching and learning process using TTW strategy in constructing recount text showed that the students were involved actively in teaching and learning process. Therefore, they were able to write well. And also the teacher applied Think-Talk-Write (TTW) strategy during teaching and learning process well in order to the strategy could minimize the students ${ }^{\text {ee }}$ difficulties which they faced in writing.

\section{CONCLUSION}

The use of Think Talk Write strategy in teaching writing recount text can help students of the ten grade students of SMA Setia Budi Abadi Perbaungan and motivate the students in learning writing a recount text. It can be seen from their enthusiastic and performance in writing as well. Students become more creative and active to learn and write factual recount. The implementation of using Think Talk Write strategy can be done in group where the students can work together and share the ideas each other. Thus, Teacher creates the innovative teaching so that the objectives of teaching 
writing can be achieved by the students and they feel freely in expressing the ideas without being lazy and passive.

\section{References}

[1] Dirgeyasa, I. W. 2016. College Academic Writing A Genre-Based Perspective. Jakarta: Kencana.

[2] D. Nessel, M Jones, and C. Dixon, 1989. Thinking Through the Language Arts. Macmillan.

[3] Freeman, Diane Larsen and Michael h. Long. (1991). An Introduction to second Languag Acquisition Research. London: Longman.
[4] Gerot, L \& Wignal. 1994. Making Sense of Functional Grammar. Sydney: Antipodean Education Enterprises.

[5] Huda, M. 2013. Model-Model Pengajaran dan Pembelajaran. Yogyakarta: Pustaka Belajar.

[6] Huinker, D. and Laughlin, C. 1996. „Talk your way into writing in P. Elliot \& M Kenny (eds) Communication in Mathematics', K-12 and beyond, National.

[7] Li, X. 2012. The Application of "Three Dimensional" Model in the Teaching Design of EFL Writing. English Language Teaching , 6: 32-44.

[8] Suminar, P. R., \& Putri, Giska. 2015. The Effectiveness of Think-TalkWrite Strategy in Teaching Writing Descriptive Text. Journal of English Language and Learning, Vol. 2 No. 2.

[9] Yamin, Martinis and Bansu I. Ansari. 2008. Taktik Mengembangkan Kemampuan Individual Siswa. Jakarta: Putra Grafika. 